\title{
Social Welfare Analysis of China's High-Speed Rail Industry: Based on the Perspective of Enterprises' Entry in Upstream Market
}

\author{
Da Li iD and Xiaoyan Lin \\ School of Economics and Management, Beijing Jiaotong University, Beijing 100044, China \\ Correspondence should be addressed to Da Li; 18113009@bjtu.edu.cn
}

Received 26 March 2020; Revised 30 April 2020; Accepted 23 May 2020; Published 15 June 2020

Academic Editor: Wenqing Wu

Copyright ( $92020 \mathrm{Da}$ Li and Xiaoyan Lin. This is an open access article distributed under the Creative Commons Attribution License, which permits unrestricted use, distribution, and reproduction in any medium, provided the original work is properly cited.

\begin{abstract}
Based on the analysis of the high-speed rail industry chain, first, this paper divides the high-speed rail industry chain into infrastructure construction market and manufacturing market of mobile equipment and, second, this paper uses the empirical method of new experience industry organization to measure the market power premium of the high-speed rail upstream market. The study shows that the market power premium of the high-speed rail upstream market is 0.551 , and the scale elasticity is 0.314 , indicating that there is no systematic market power in the high-speed rail upstream market and there is significant scale diseconomy. The vertical market structure where "private enterprises dominate the upstream competition market and state-owned enterprises dominate the downstream oligopoly market" is further established. Based on the perspective of enterprises' entry in upstream markets, the social welfare of the high-speed rail industry market structure is analyzed. It is found in the study that the upstream market of the high-speed rail industry has a tendency of insufficient enterprise entry, and the total social welfare increases with the increase in the number of upstream enterprises entry. What is more, the profit of enterprises in the upstream market of high-speed rail decreases with the increase in the number of enterprises in the upstream. This paper believes that policies such as stimulating upstream high-speed rail enterprises entry, providing subsidies to upstream enterprises, reducing upstream enterprises' entry barriers, and expanding international markets can effectively improve the overall social welfare of the highspeed railway industry.
\end{abstract}

\section{Problem Presentation}

Since the reform and opening up 40 years ago, with the deepening of the market-oriented reform of state-owned enterprises, China's downstream product market has basically achieved free competition, and the market mechanism has gradually played a decisive role in resource allocation. Ji and Guo estimated the upstream market of 122 sectors in China. The results showed that, in the industries of oil, natural gas, iron ore, heavy metal, and other raw materials supply and energy exploitation [1], state-owned enterprises dominated the upstream market, while in the industries of product service, operation, and sales, private enterprises dominated the downstream market [2]. According to the estimation of Wang and Shi, the average value of the Herfindahl index of China's upstream industries in 2007 was 0.21 . According to the US Department of Justice's HHI measure of industrial concentration, the market structure corresponding to this value is an oligopoly structure [3]. To sum up, China's domestic market has basically formed a vertical structure in which "state-owned enterprises dominate the upstream market and private enterprises dominate the downstream market" (Liu [4], Li et al. [5], and Qian [6]).

The traditional railway transportation industry has public welfare attributes and aims to provide cheap transportation services [7]. China's railway transportation industry has many problems and phenomena that inhibit industrial development and reduce social welfare, such as high investment, high debt, low efficiency, and low profit [8]. China has successively implemented policies such as railway privatization reform, railway industry restructuring, and internal competition in the railway industry. The market-oriented reform of railway transportation enterprises has become a major trend. Different from the 
traditional railway transportation industry, the high-speed railway industry meets the higher-level needs of passengers, including the saving of travel time, the comfort of the journey, and the services of additional products. Therefore, the high-speed railway transportation service is not a traditional public welfare transportation service.

As a special railway transportation industry, does the market structure of the high-speed rail industry conform to the vertical structure of "state-owned enterprises dominating the upstream market monopoly and private enterprises dominating the downstream market competition" that has been formed in the domestic market? What are the constraints in the development of the high-speed rail industry? How to improve the overall social welfare through industrial or competition policies? Based on the analysis of the high-speed rail industry, this paper divides the highspeed rail industry into an upstream market focusing on the infrastructure construction and mobile equipment manufacturing, and a downstream market focusing on providing passenger transportation services adopts the empirical method of new experience industrial organization to measure the upstream market power of the high-speed rail and establishes an asymmetrically distributed vertical structure of the upstream and downstream markets in which "private enterprises dominate the upstream competition market and state-owned enterprises dominate the downstream oligopoly market." Based on the perspective of enterprises' entry in the upstream market, the social welfare situation of the market structure of the high-speed rail industry is analyzed, and the research results provide useful reference suggestions for improving the overall social welfare of the high-speed rail industry. The research framework of this paper is shown in Figure 1.

\section{Literature Review}

The purpose of high-speed rail development is to provide fast, comfortable, and safe passenger transport services with large volume, high speed, and low pollution. According to the Medium- and Long-Term Railway Network Planning of 2016, the high-speed railway network expanded from "four vertical and four horizontal planning" to "eight vertical and eight horizontal one." It is estimated that, by 2020 , the highspeed railway operation mileage will reach 30000 kilometers and, by 2025, the mileage will reach 38000 kilometers. At that time, the high-speed rail network will connect almost all large- and medium-sized cities in China, and the time travel distance between adjacent cities will not exceed one hour. By 2018, China's high-speed rail has exceeded 29000 kilometers, ranking first in the world [9].

With the rapid expansion of China's high-speed rail network, the development of high-speed rail industry has been gradually valued and challenged. Most of the previous studies focused on the relationship between high-speed rail and national economy (Lin et al. [10], Zhao et al. [11], Wu et al. [12], and Chen and Haynes [13]), the relationship between high-speed rail and regional development (Lin et al. [14] and $\mathrm{Hu}$ et al. [15]), and the competition between highspeed rail and other modes of transportation (Wang et al. [16],
D'Alfonso et al. [17], and Wang et al. [18]). For example, Tang Rong and Gu Naihua (2018) used the method of PSM-DID to empirically analyze the impact of high-speed rail development on the productive services and found that the appearance of high-speed rail reduced the revenue of productive services and there is regional heterogeneity [19]; Lin Xiaoyan (2015) used the yes-no method to analyze the impact of WuhanGuangzhou high-speed railway on talent attraction. The study found that the high-speed railway can effectively promote the flow of factors and increase the talent agglomeration effect of cities along the railway [10]; Hu Jing (2015) used the Herfindahl index to measure the industrial agglomeration of the tourism industry in Hubei Province. The study showed that the high-speed rail has increased the industrial agglomeration level of the tourism industry in Hubei Province, but there are significant regional differences [15]; D’Alfonso (2015) constructed a duopoly model of high-speed rail and civil aviation and analyzed the competition impact of high-speed rail and civil aviation. The study showed that even if the level of pollutants emitted by high-speed rail is much lower than that of civil aviation, because the substitution effect and the stimulation effect coexist simultaneously, the large-induced demand may make the high-speed rail have a net negative effect on the environment [17].

There are few researches regarding the high-speed rail as a complete industrial chain system. Jiang Mingyi (2019) analyzed the correlation effect of the high-speed rail industry on related industries from an industrial perspective. The study found that the backward correlation effect of the highspeed rail is mainly manifested in mechanical equipment manufacturing and metal product manufacturing. The forward correlation effect of the high-speed rail is mainly manifested in finance and education, services, and other tertiary industries [20]. In this paper, the high-speed railway is regarded as a complete industrial chain system, and the high-speed railway industry is divided into the upstream market mainly for infrastructure construction and mobile equipment manufacturing and the downstream market mainly for providing passenger transport services. The empirical method of new experience industrial organization is used to measure the upstream market power. Based on the analysis of the upstream and downstream markets of the high-speed railway industry, the asymmetrical vertical structure of the upstream and downstream markets in which "private enterprises dominate the upstream competition market and state-owned enterprises dominate the downstream oligopoly market" is constructed. And the social welfare of the high-speed rail industry market structure is analyzed based on the perspective of enterprises' entry in the upstream market.

\section{Market Segmentation of High-Speed Rail Industry}

3.1. Upstream Market of High-Speed Rail Industry. High-speed railway industry is a high-tech complex system including engineering design, infrastructure construction (high-speed railway network construction), mobile equipment manufacturing (high-speed railway EMU 


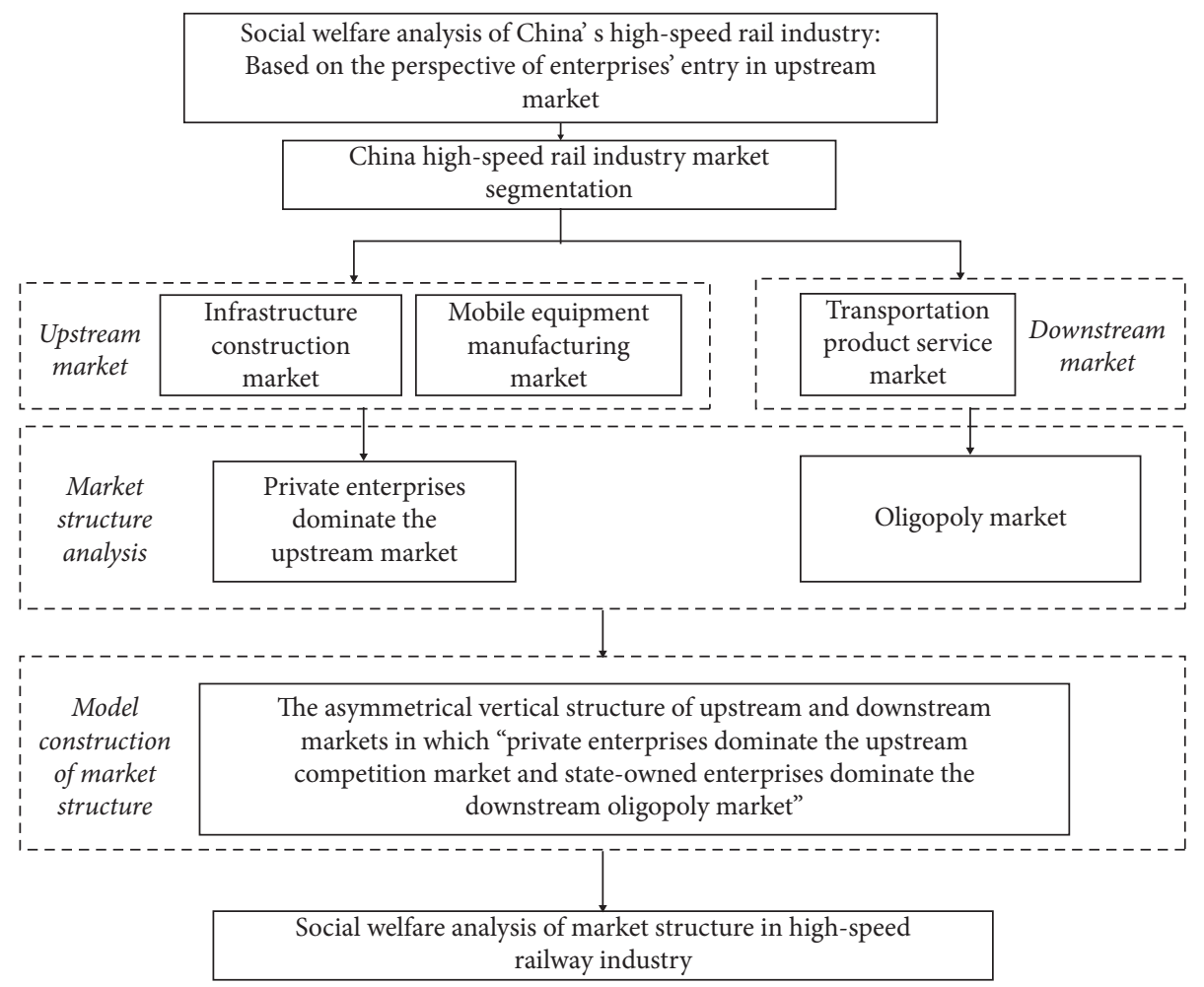

FIgURE 1: The research framework of this study.

manufacturing), communication signal and control system, operation and maintenance, and other subsystems ( $\mathrm{Lv}$ and $\mathrm{He}[21]$ ), in which the upstream industry chain of highspeed rail includes enterprises which engage in high-speed rail network infrastructure construction, mobile equipment manufacturing, and other enterprises [22]; the downstream industry chain of high-speed rail is the passenger transport service enterprises. This article used the empirical method of new experience industrial organization to measure the market power of the high-speed rail industry upstream market by drawing on the methods of Yu and Jiang [23] and Zhang and Zhang [24].

3.1.1. Regression Estimation Model. The empirical method of new experience industrial organization was first proposed by Bresnahan. This method uses the economic data of the industry to evaluate the market power of the monopoly market through the estimation model of Solow production function and does not need the accounting data which are difficult to obtain. Hall extended the traditional NEIO model, but his assumption of constant returns to scale is not in line with the actual situation. Kettle revised the assumption of constant returns to scale to improve the model [25]. This article uses Kettle's improved NEIO model to measure the premium situation of the upstream market power of the high-speed rail industry.

The production function that introduces technological changes and scale differences is shown in the following equation, where $Q_{i t}$ represents the output of company $i$ in period $t, X_{i t}$ represents the factor input of company in period $t$, and $A_{i t}$ represents the technology progress:

$$
Q_{i t}=A_{i t} * F_{i t}\left(X_{i t}\right) \text {. }
$$

Assuming a representative enterprise $Q_{t}=A_{t} * F_{t}\left(X_{t}\right)$, make the difference on the logarithm of the production function:

$$
\ln Q_{i t}-\ln Q_{t}=\ln A_{i t}-\ln A_{t}+\ln F_{i t}\left(X_{i t}\right)-\ln F_{t}\left(X_{t}\right) .
$$

Assuming $q_{i t}^{*}=\ln Q_{i t}-\ln Q_{t}, \quad a_{i t}^{*}=a_{i t}^{*}=\ln A_{i t}-\ln A_{t}$, and $x_{i t}^{*}=\ln X_{i t}-\ln X_{t}$, from the transformation of differential mean value theorem, we can get the following result:

$$
q_{i t}^{*}=a_{i t}^{*}+\sum_{j=1}^{m} \alpha_{i t}^{j} x_{i t}^{* j} .
$$

According to the equilibrium condition $\mathrm{MFC}=\mathrm{VMP}$, the following result is obtained:

$$
w_{i t}^{j}=p *\left(1-\frac{1}{\mu}\right) * A_{i t} * \frac{\partial F_{i t}}{\partial X_{i t}^{j}} .
$$

It can be obtained from $\lambda=P / \mathrm{MC}=1 /(1-1 / \mu)$ :

$$
q_{i t}^{*}=a_{i t}^{*}+\lambda_{i t} \sum_{j=1}^{m} \rho_{i t}^{j} x_{i t}^{* j} .
$$

The elements of capital investment are needed to be separated, wherein $\eta_{i t}$ represents the scale elasticity and $\rho_{i t}^{j}$ represents the proportion of input of noncapital elements in total output, so it can be obtained: 


$$
q_{i t}^{*}=a_{i t}^{*}+\lambda_{i t} \sum_{j \neq k}^{m} \rho_{i t}^{j}\left(x_{i t}^{* j}-x_{i t}^{* k}\right)+\eta_{i t} x_{i t}^{* k} .
$$

The fixed effect is removed by $a_{i t}^{*}=a_{i}+\mu_{i t}$, and the autocorrelation is eliminated by first-order difference:

$$
\Delta q_{i t}^{*}=\lambda * \Delta x_{i t}^{* v}+\eta x_{i t}^{* k}+\Delta v_{i t} .
$$

Then, the regression estimation equation is obtained:

$$
q_{i t}^{*}=\alpha+\lambda x_{i t}^{* v}+\eta x_{i t}^{* k}+\mu_{i t},
$$

where in $x_{i t}^{* k}$ is the input of capital elements, $x_{i t}^{* j}$ is the investment of noncapital elements, $x_{i t}^{* v}=\sum_{j \neq k} S_{i j}^{-j l}\left(x_{i t}^{* j}-x_{i t}^{* k}\right)$, and $S_{i j}^{-j}$ is the proportion of input factor $j$ in the total output of the enterprise. Because of the significant correlation between the error term $\mu_{i t}$ and the explanatory variable $x_{i t}^{* v}$, it is necessary to use the instrumental variable to solve the endogenous problem.

\subsubsection{Major Listed Companies in the Upstream Market of} High-Speed Rail Industry. According to the analysis of this paper, the upstream market of high-speed rail industry includes the infrastructure construction market and the market of mobile equipment, parts, and materials. Therefore, 15 major listed companies in the upstream market of highspeed rail industry are selected, and the situation of major listed companies is shown in Table 1.

3.1.3. Variable Selection. The output data select the operating income of the manufacturers in the upstream industry of high-speed rail transportation as the total value of the final products of the manufacturers' input factors. The input factors are capital input, labor input, and raw material input. Among them, the capital element is mainly in the depreciation of fixed assets, the labor element is the employee compensation and pay, and the raw material element is mainly the cash paid for the raw materials, energy, and auxiliary services purchased from outside [26].

This study selects 15 major listed companies related to the upstream market of the high-speed rail industry as a sample. The main businesses involved include infrastructure construction, mobile equipment manufacturing, production of parts and materials, etc.; the operating income, employee compensation level, depreciation of fixed assets, cash payment for purchase of goods and services, and other indicators from 2010 to 2018 of the 15 major listed companies are selected, and data sources are annual reports, audit reports, and Guotai'an databases of listed companies.

3.1.4. Estimation Results. $\lambda$ is the market power premium of the upstream market of high-speed rail, $\eta$ is the scale effect, and $\alpha$ is the intercept phase, reflecting the production efficiency difference between different upstream enterprises. The estimation results are shown in Table 2. The market power premium of the high-speed rail upstream market is 0.551 , which is significant at $1 \%$, indicating that there is no systematic market power in the high-speed rail upstream market, and the market power premium is less than 1. It can be seen that there is sufficient competition among enterprises in the upstream market; the elasticity of scale is 0.314 , which indicates that there is significant scale diseconomy among enterprises in the upstream market, and there may be insufficient entry tendency of enterprises in the upstream market of high-speed rail.

3.1.5. Robustness Test. Considering the autocorrelation between the error term and the input factors, this paper selects the total capital and the number of employees as the instrumental variables to test the robustness. The results of the robustness test are shown in Table 3. The market power premium is significantly less than 1 , and the scale elasticity is significantly less than 1 , which indicates that there is no market power in the upstream market, and the upstream enterprises have significant scale diseconomy. The above model results are stable.

3.2. Downstream Market of High-Speed Rail Industry. The downstream market of the high-speed rail industry mainly refers to the passenger transport market that provides transportation products. The high-speed rail has an advantageous position in terms of speed, safety, comfort, and environmental protection. A significant phenomenon of the appearance of the high-speed rail is the impact on civil aviation. According to data from the World Bank Report (2018), the high-speed rail has reduced the service of Guangzhou to Wuhan by half, the service of the GuangzhouChangsha flight has been reduced by two-thirds, and the Zhengzhou-Xi' an high-speed rail has forced the cancellation of this aviation route. The Nanjing-Wuhan high-speed rail has forced the aviation route to reduce 6 pairs of flights per day. Wei et al. found that the average ticket price of the Beijing-Shanghai aviation fell by about $29 \%$ after the appearance of high-speed railway between the BeijingShanghai but rebounded by about $20 \%$ after the Wenzhou high-speed rail accident [27]. This phenomenon not only takes place in China but also forces JAL to stop its flights from Tokyo to Osaka and Tokyo to Nagoya after the appearance of Shinkansen; the TGV high-speed rail project in France causes Air France to lose the market share of air from Paris to Lyon; the opening of high-speed rail in Britain causes BIM Airlines to stop some flights from London to Paris; after the construction of high-speed rail from Seoul to Busan in South Korea, the corresponding market share of civil aviation has declined dramatically [28].

The competition between high-speed rail and civil aviation is mainly reflected in the short-term and long-term impacts of ticket price, profit, frequency, seat capacity, network layout, and social welfare (Wan et al. [29], D’Alfonsoet al. [17], Ding et al. [30], Behrens and Pels [31], Jiang and Zhang [32], Xia and Zhang [33], and Yang and Zhang [34]). Yu et al. studied and analyzed the characteristics of the high-speed rail industry organization and its antitrust applicability. The study found that the high-speed rail industry does not generally belong to the natural monopoly industry. It further demonstrated that the high-speed 
TABLE 1: Main listed companies in the upstream market of high-speed rail industry.

\begin{tabular}{|c|c|c|c|}
\hline High-speed rail industry & Market segmentation & Name of the company & Main business \\
\hline \multirow{16}{*}{$\begin{array}{l}\text { Upstream market of the high- } \\
\text { speed rail industry chain }\end{array}$} & \multirow{6}{*}{ Infrastructure construction market } & China Railway & $\begin{array}{l}\text { Engineering } \\
\text { infrastructure }\end{array}$ \\
\hline & & China Railway Construction & $\begin{array}{l}\text { Engineering } \\
\text { infrastructure }\end{array}$ \\
\hline & & China Railway Second Bureau & $\begin{array}{l}\text { Engineering } \\
\text { infrastructure }\end{array}$ \\
\hline & & China Communications & Engineering \\
\hline & & Construction Co., Ltd. & infrastructure \\
\hline & & $\begin{array}{c}\text { China Construction Group Co., } \\
\text { Ltd. }\end{array}$ & $\begin{array}{l}\text { Engineering } \\
\text { infrastructure }\end{array}$ \\
\hline & \multirow{10}{*}{$\begin{array}{l}\text { Manufacturing market of mobile } \\
\text { equipment, parts, and materials }\end{array}$} & STEC & $\begin{array}{l}\text { Engineering } \\
\text { infrastructure }\end{array}$ \\
\hline & & CRRC & EMU manufacturing \\
\hline & & JXAC & $\begin{array}{l}\text { Railway axle } \\
\text { manufacturing }\end{array}$ \\
\hline & & Liyuan Refining & $\begin{array}{l}\text { Transportation } \\
\text { equipment }\end{array}$ \\
\hline & & $\begin{array}{c}\text { Zhuzhou Times New Material } \\
\text { Technology Co., Ltd }\end{array}$ & $\begin{array}{l}\text { Equipment } \\
\text { manufacturing }\end{array}$ \\
\hline & & Northern Entrepreneurship & $\begin{array}{l}\text { Transportation } \\
\text { materials }\end{array}$ \\
\hline & & Jinyi Industry & $\begin{array}{l}\text { Transportation } \\
\text { materials }\end{array}$ \\
\hline & & Oak Shares & Parts and materials \\
\hline & & $\begin{array}{c}\text { AVIC Optoelectronics Technology } \\
\text { Co., Ltd. }\end{array}$ & Parts and materials \\
\hline & & Daye Special Steel & Parts and materials \\
\hline
\end{tabular}

Source: annual reports, audit reports, and Guotai'an databases of listed companies.

TABLE 2: The estimation results of 2SLS model.

\begin{tabular}{lcc}
\hline Estimated coefficient & Estimated value & $\begin{array}{c}\text { Standard } \\
\text { deviation }\end{array}$ \\
\hline Market power premium $(\lambda)$ & $0.551^{* * *}$ & 0.039 \\
Scale elasticity $(\eta)$ & $0.314^{* * *}$ & 0.045 \\
Efficiency difference $(\alpha)$ & $4.815^{* * *}$ & 0.668 \\
$R^{2}$ & \multicolumn{2}{c}{$0.9691^{* * *}$} \\
\hline
\end{tabular}

Note: ${ }^{* * *},{ }^{* *}$, and ${ }^{*}$ indicate that the estimated coefficients of the variable are significant at the level of $1 \%, 5 \%$, and $10 \%$, respectively. ${ }^{*} p<0.1 ;{ }^{* *} p<0.05$; ${ }^{* * *} p<0.01$.

TABLE 3: The tool variable estimation results of 2 SLS model.

\begin{tabular}{lcc}
\hline Estimated coefficient & Estimated value & $\begin{array}{c}\text { Standard } \\
\text { deviation }\end{array}$ \\
\hline Market power premium $(\lambda)$ & $0.1961^{* * * *}$ & 0.067 \\
Scale elasticity $(\eta)$ & $0.4071^{* * *}$ & 0.076 \\
Efficiency difference $(\alpha)$ & $10.9371^{* * *}$ & 1.174 \\
$R^{2}$ & \multicolumn{2}{c}{$0.88071^{* * *}$} \\
\hline
\end{tabular}

Note: ${ }^{* * *},{ }^{* *}$, and ${ }^{*}$ indicate that the estimated coefficients of the variable are significant at the level of $1 \%, 5 \%$, and $10 \%$, respectively. ${ }^{*} p<0.1 ;{ }^{* *} p<0.05$; ${ }^{* * *} p<0.01$

rail industry is also applicable to the antitrust law. And it is proposed that the upstream locomotive manufacturing and road network construction of high-speed rail industry are highly competitive market structures, and the downstream road network operation of high-speed rail industry is a competitive market (partial monopoly) [35]. Therefore, this study holds that the passenger transport market downstream of high-speed rail industry is an oligopoly market.

\section{Construction of High-Speed Rail Industry Market Structure Model}

Through analysis, it is shown that high-speed rail industry has formed a special vertical structure in China, that is, an asymmetrically distributed vertical structure of upstream and downstream markets in which "private enterprises dominate the upstream competition market and stateowned enterprises dominate the downstream oligopoly market." This study calls it the " $n+2$ " vertical market structure.

The industry chain of high-speed rail is thought of as a closed economy, including infrastructure construction and mobile equipment manufacturing in the upstream market and transportation products and services in the downstream market. The model assumes that the upstream market is dominated by private enterprises, the market structure is set as monopoly competition, the downstream is dominated by state-owned enterprises, and the market structure is set as a duopoly market. It is assumed that the enterprises in the upstream competitive market are homogeneous, $w$ is the price of the differentiated products provided by the upstream enterprises, $c$ is the marginal cost of the upstream enterprises, $d$ is the scale return coefficient of the upstream enterprises, $d$ is the output of the upstream single enterprise, 
and $f$ is private enterprise entry cost in the upstream; $p$ is the price of state-owned enterprises in the downstream, $f_{0}$ is the fixed cost of oligarch 1 in the downstream market, $c_{0}$ is the intermediate product input cost of oligarch 2 in the downstream market, $q_{1}$ is the output of oligarch 1 , and $q_{2}$ is the output of oligarch 2 .

The counterdemand function of an individual enterprise in the upstream market is

$$
w=m-\varepsilon d-\eta D .
$$

That is,

$$
w=m-\varepsilon d-\eta n d,
$$

where $\varepsilon$ represents the difference in producing homogeneous products and $\eta$ represents the elasticity of substitution of differentiated products.

The profit of a single enterprise in the upstream market is

$$
\pi=(w-c) d-f .
$$

The equilibrium output of upstream enterprises is obtained based on profit maximization conditions:

$$
d^{*}=\frac{m-c}{\varepsilon+n \eta} \text {. }
$$

The counterdemand function of the downstream duopoly market is

$$
p=a-\gamma\left(q_{1}+q_{2}\right)
$$

According to the profit maximization conditions, the response curve is

$$
\begin{aligned}
& q_{1}=\frac{a-\gamma q_{2}-w}{2 \gamma}, \\
& q_{2}=\frac{a-\gamma q_{2}-c_{0}}{2 \gamma} .
\end{aligned}
$$

According to the conditions of profit maximization, the equilibrium output $q_{1}^{*}$ and the equilibrium price of the oligarch 1 are further obtained:

$$
\begin{aligned}
& q_{1}^{*}=\frac{a+c_{0}-2 w}{3 \gamma}, \\
& p^{*}=\frac{a+c_{0}+w}{3} .
\end{aligned}
$$

According to the conditions of equal supply and demand in the upstream and downstream, we can get the following:

$$
w^{*}=\frac{a+c_{0}}{2}-\frac{3 b n \gamma(m-c)}{2(\varepsilon+n \eta)} .
$$

\section{Social Welfare Analysis of Market Structure of High-Speed Rail Industry}

Based on the above model assumptions and model construction, the social welfare is further calculated as follows:

$$
\begin{aligned}
s w & =\pi_{u}+\pi_{d}+c s=n\left[(w-c) d^{*}-f\right]+\left(p^{*}-w\right) q_{1}^{*}-f_{0}+\frac{\left(a+c_{0}-2 p^{*}\right)}{2 \gamma}\left(\frac{a+c_{0}}{2}-p^{*}\right) \\
& =\frac{(m-c)\left(n c_{0} \mp a n-2 n c\right)}{2(\varepsilon+n \eta)}-\frac{3 n^{2} b \gamma(m-c)^{2}}{2(\varepsilon+n \eta)^{2}}-n f+\frac{5[3 n b \gamma(m-c)]^{2}}{36 \gamma(\varepsilon+n \eta)^{2}}-f_{0} .
\end{aligned}
$$

Based on the conditions for maximizing social welfare, the following is obtained:

$$
\frac{\partial s w}{\partial n}=\frac{\varepsilon(m-c)\left(a+c_{0}-2 c\right)}{2(\varepsilon+n \eta)^{2}}+\frac{n \varepsilon b \gamma(m-c)^{2}(5 b-6)}{2(\varepsilon+n \eta)^{3}}-f>0 .
$$

After calculation,

$$
\begin{aligned}
\frac{\partial s w / \partial n}{\partial n}= & -\varepsilon(m-c)\left(a+c_{0}-2 c\right) \frac{\eta(\varepsilon+n \eta)}{\varepsilon+n \eta^{4}} \\
& -\frac{b \gamma \varepsilon(m-c)^{2}(6-5 b)}{2} \frac{(\varepsilon+n \eta)^{2}(\varepsilon-2 n \eta)}{(\varepsilon+n \eta)^{6}}<0 .
\end{aligned}
$$

According to the market equilibrium conditions, when $n$ approaches $0, \partial s w / \partial n$ approaches $(m-c)\left(a+c_{0}-2 c\right) / 2 \varepsilon-f>0$; when $n$ approaches infinity, $\partial s w / \partial n$ approaches $-f<0$. Therefore, when $n$ is small, social welfare increases with the increase in the number of companies of the upstream market. When $n$ approaches infinity, social welfare decreases with the increase in the number of companies in the upstream market, showing an inverted U-shaped structure. The diagram of the inverted U-shaped structure is shown in Figure 2.

The two parts of social welfare of consumer surplus and downstream market are further calculated:

$$
\frac{\partial\left(\pi_{d}+c s\right)}{\partial n}=\frac{5 n \varepsilon b^{2} \gamma(m-c)^{2}}{2(\varepsilon+n \eta)^{3}}>0 .
$$

According to formula (20), the two parts of social welfare of consumer surplus and the downstream market increase with the increase in the number of companies entering upstream market.

The condition of profit maximization in the upstream market is 


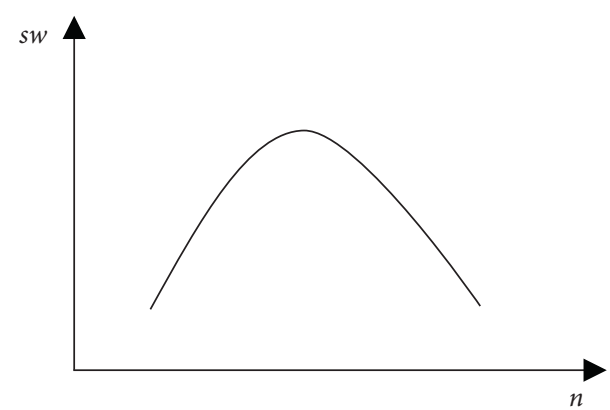

Figure 2: The diagram of the inverted U-shaped structure.

$$
\frac{\partial \pi_{u}}{\partial n}=\frac{\varepsilon(m-c)\left(a+c_{0}-2 c\right)}{2(\varepsilon+n \eta)^{2}}-\frac{3 n \varepsilon b \gamma(m-c)^{2}}{(\varepsilon+n \eta)^{3}}-f<0 .
$$

It can be known from $\partial \pi_{u} / \partial n<0$ that, with the increase in the number of enterprises in the upstream market, the profit of enterprises in the upstream market decreases. There is a tendency of insufficient entry of enterprises in the upstream market.

It can be seen from the derivation and analysis of the above model that the profit of enterprises in the upstream market of high-speed rail decreases with the increase in the number of enterprises in the upstream. When the profit of enterprises in the upstream market is less or close to zero, the upstream enterprises will refuse to enter the upstream market, so there is a tendency of insufficient entry of enterprises in the upstream market, while the sum of the two parts of social welfare of the downstream market of highspeed rail and the consumer surplus will increase with the increase in the number of enterprises in the upstream market. It can be seen that private enterprises continue to enter the upstream market, although their profits are damaged, which can increase consumers' social welfare in the downstream oligopoly market.

\section{Conclusions and Policy Suggestions}

First of all, through the in-depth analysis of the high-speed rail industry, this paper divides the high-speed rail industry market into high-speed rail upstream market dominated by high-speed rail infrastructure construction and mobile equipment manufacturing enterprises and high-speed rail downstream market dominated by passenger transport service enterprises. The empirical method of new experience industrial organization is used to calculate the market power premium and scale elasticity of the upstream market of highspeed rail to be 0.551 and 0.314 , respectively, which indicates that there is no systematic market power and significant scale diseconomy in the upstream market of high-speed rail. A special vertical market structure model of China's highspeed rail industry is constructed in this paper. Contrary to the market structure of other industrial sectors in China, the market structure of China's high-speed rail industry is an asymmetrically distributed vertical structure of upstream and downstream markets, in which private enterprises dominate the upstream competition market and stateowned enterprises dominate the downstream oligopoly market.

Secondly, based on the special vertical structure model of China's high-speed rail industry, the social welfare of the high-speed rail industry under this vertical structure is discussed from the perspective of the number of enterprises entering the upstream market. The study found that the number of enterprises in the upstream market is a key constraint on the total social welfare of the high-speed rail industry. The total social welfare of the high-speed rail industry has an inverted U-shaped relationship with the number of enterprises entering the upstream market. With the increase in number of companies of the upstream market, the profits of enterprises in the upstream market gradually decrease, while the sum of social welfare in the downstream market and consumer surplus gradually increases, which indicates that there is a tendency of insufficient enterprises entry in the upstream, and the number of upstream enterprises entry restricts the improvement of social welfare of high-speed rail industry.

Therefore, the following suggestions are put forward in this paper: first, the use of industrial policies. Encourage private enterprises to enter the upstream market of the high-speed rail industry through the government's policy means, that is, highspeed rail network infrastructure construction and mobile equipment manufacturing market. The policies may include tax relief, tax allowance and credit, and financial subsidies for enterprises related to the upstream market of high-speed rail; second, implement competition policies, deepen the reform of state-owned enterprises in the downstream market of highspeed rail, introduce competition within high-speed rail enterprises, and break the monopoly of the industrial chain. In December 2018, the China Railway Corporation was officially renamed as China National Railway Group Co., Ltd., which has completely realized the reform of the railway company system so far. At the same time, it is also a key step in transforming to a modern transportation business enterprise, which conforms to the reform thinking of the market-oriented economic system. Third, strengthen the "high-speed rail going out" strategy, expand the scope of the high-speed rail upstream market, and gradually open the international market for high-speed rail infrastructure construction and high-speed rail EMU manufacturing. In August 2019, CRRC Zhuzhou Locomotive Co., Ltd. acquired the locomotive business of the international railway giant German Vossloh. It can be seen that the international railway infrastructure construction and mobile equipment manufacturing are moving towards a direction of professional division of labor and higher efficiency.

\section{Data Availability}

Annual reports and audit reports of listed companies and Guotai'an databases were used to support this study.

\section{Conflicts of Interest}

The authors declare that there are no conflicts of interest. 


\section{Acknowledgments}

This study was supported by the major project of the $\mathrm{Na}$ tional Social Science Foundation of China (Research on the Analytical Framework and Evolution Path of China's HighSpeed Rail Economy) (17ZDA084).

\section{References}

[1] Q. Ji and J.-F. Guo, "Oil price volatility and oil-related events: an internet concern study perspective," Applied Energy, vol. 137, no. 1, pp. 256-264, 2015.

[2] J. Ju and X. Yu, "Productivity, profitability, production and export structures along the value chain in China," Journal of Comparative Economics, vol. 43, no. 1, pp. 33-54, 2015.

[3] Y. Wang and B. Shi, "Upstream monopoly and product quality upgrade of Chinese enterprises," Economic Research, vol. 49, no. 4, pp. 116-129, 2014.

[4] R. Liu, "State-owned enterprises, implicit subsidies and market segmentation: theoretical and empirical evidence," World of Management, vol. 4, pp. 21-32, 2012.

[5] X. Li, X. Liu, and Y. Wang, "A model of china's state capitalism," in Proceedings of the HKSTU Working Paper, 2015.

[6] X. Qian, J. Zhang, and H. Mao, "Vertical structure, misplacement of resources and industrial policy," Economic Research, vol. 54, no. 2, pp. 54-67, 2019.

[7] M. Rizk, "Rizk-allah, aboul ella hassanien, mohamed elhoseny, A multi-objective transportation model under neutrosophic environment," Computers and Electrical Engineering, vol. 69, pp. 705-719, July 2018.

[8] J. Chen, X. Wang, and Z. Chu, "Capacity sharing, product differentiation and welfare," Economic Research-Ekonomska Istraživanja, vol. 33, no. 1, pp. 107-123, 2020.

[9] M. R. Reddy, K. G. Srinivasa, and B. E. Reddy, "Smart vehicular system based on the internet of things," Journal of Organizational and End User Computing, vol. 30, no. 3, pp. 45-62, 2018.

[10] X. Lin, Z. Shi, Y. Luo et al., "Analysis of the influence of highspeed railways on the attraction of urban talents," Journal of Beijing Jiaotong University (Social Science Edition), vol. 14, no. 3, pp. 7-16, 2015.

[11] J. Zhao, Y. Zhao, and Y. Li, "The variation in the value of travel-time savings and the dilemma of high-speed rail in China," Transportation Research Part A: Policy and Practice, vol. 82, no. 82, pp. 130-140, 2015.

[12] J. Wu, C. Nash, and D. Wang, "Is high speed rail an appropriate solution to China's rail capacity problems?" Journal of Transport Geography, vol. 40, no. 40, pp. 100-111, 2014.

[13] Z. Chen and K. E. Haynes, "Impact of high speed rail on housing values: an observation from the Beijing-Shanghai line," Journal of Transport Geography, vol. 43, no. 43, pp. 91-100, 2015.

[14] X. Lin, X. Chen, Y. Bai et al., "Quantitative analysis of the impact of beijing-tianjin intercity high-speed railway on regional economy," Railway Economic Research, vol. 5, pp. 5-11, 2010.

[15] J. Hu, L. Cheng, and Mi Zhou, "Impact of high-speed rail on the agglomeration level of tourism industry in Hubei Province," Journal of Chongqing Jiaotong University (Social Science Edition), vol. 15, no. 5, pp. 22-26, 2015.

[16] K. Wang, W. Xia, and A. Zhang, "Should China further expand its high-speed rail network? consider the low-cost carrier factor," Transportation Research Part A: Policy and Practice, vol. 100, no. 100, pp. 105-120, 2017.
[17] T. D’Alfonso, C. Jiang, and C. Jiang, "Would competition between air transport and high-speed rail benefit environment and social welfare?" Transportation Research Part B:Methodological, vol. 74, pp. 118-137, 2015.

[18] C. Wang, J. Yue, and H. Yang, "Measurement of substitution effect of high-speed railway on domestic civil passenger transport," Journal of Natural Resources, vol. 34, no. 9, pp. 1933-1944, 2019.

[19] R. Tang and N. Gu, "High-speed railway construction and the development of upstream productive service industry-an empirical test based on PSM-DID," Economic and Management Research, vol. 39, no. 7, pp. 58-68, 2018.

[20] M. Jiang, "Research on High-Speed Rail Industry and its Related Effects-Based on the 2012 Input-Output Table," M.S. Thesis, Beijing Jiaotong University, Beijing, China, 2019.

[21] T. Lv and J. He, "How effective the government intervention is: investigation and research on China's high-speed rail technology catch-up," Management World, vol. 35, no. 9, pp. 152-163, 2019.

[22] Z. Lv, B. Hu, and H. Lv, "Infrastructure monitoring and operation for smart cities based on IoT system," IEEE Transactions on Industrial Informatics, vol. 16, no. 3, pp. 1957-1962, 2019.

[23] L. Yu and Qi. Jiang, "Two-sided market power, asymmetric competition and reform path selection-on the dilemma and reform of China's railway transportation industry," China Industrial Economy, vol. 4, pp. 133-145, 2013.

[24] Z. Zhang and M. Zhang, "Market power, coal and electricity contradictions and potential welfare loss: empirical evidence from listed companies," Research on Industrial Economy, vol. 1, pp. 21-30, 2011.

[25] T. J. Klette, "Market power, scale economics and productivity: estimates from a panel of establishment data," The Journal of Industrial Economics, vol. 47, no. 4, pp. 451-476, 2003.

[26] N. Szumilo, "How do office buildings take advantage of energy efficiency? A study of the relationship between operating expenses and energy certification," International Journal of Environmental Technology And Management, vol. 18, no. 2, pp. 116-135, 2015.

[27] F. Wei, J. Chen, and L. Zhang, "Demand shocks, airline pricing, and high-speed rail substitution: evidence from the Chinese market," Journal of Transport Economics and Policy, vol. 51, no. 4, pp. 266-289, 2017.

[28] X. Jiang, "Analysis of competition between China's civil aviation and high-speed railway," Shopping Mall Modernization, vol. 8, pp. 68-69, 2010.

[29] Y. Wan, H.-K. Ha, Y. Yoshida, and A. Zhang, "Airlines' reaction to high-speed rail entries: empirical study of the Northeast Asian market," Transportation Research Part A: Policy and Practice, vol. 94, pp. 532-557, 2016.

[30] J. Ding, F. Jin, C. Wang et al., "Competitive game between high-speed rail and civil aviation and its spatial effect: a case study of beijing-shanghai high-speed rail," Economic Geography, vol. 33, no. 5, pp. 104-110, 2013.

[31] C. Behrens and E. Pels, "Intermodal competition in the London-Paris passenger market: high-speed rail and air transport," Journal of Urban Economics, vol. 71, no. 3, pp. 278-288, 2012.

[32] C. Jiang and A. Zhang, "Airline network choice and market coverage under high-speed rail competition," Transportation Research Part A: Policy and Practice, vol. 92, pp. 248-260, 2016.

[33] W. Xia and A. Zhang, "Effects of air and high-speed rail transport integration on profits and welfare: the case of air-rail 
connecting time," Journal of Air Transport Management, (Forthcoming), 2016.

[34] H. Yang and A. Zhang, "Effects of high-speed rail and air transport competition on prices, profits and welfare," Transportation Research Part B: Methodological, vol. 46, no. 10, pp. 1322-1333, 2012.

[35] Li Yu, Z. Xu, and H. Xu, "Analysis of China's high-speed railway industry and the applicability of antitrust law," SinoGerman Law Forum, vol. 1, pp. 28-41, 2017. 